It was certainly not an attempt to offer a formula for 'a comprehensive service'. Still less was it intended to set the pattern of mental health care in tablets of stone. I hope, though, that members may find it useful as establishing a starting point for discussion. If, for instance, their local administrators accepted such norms, with qualification, for a 'bed-led' service, then they might be sympathetic to alternatives which would cost less, or at least no more. Unfortunately many of our members find their existing resources are whittled away to very unsatisfactory levels. It is not easy for them to defend themselves unless they can quote figures. Dr McGovern is right in supposing that my letter was well intentioned, but not necessarily to assist psychiatric planners to 'obtain more resources'-sometimes to help them to avoid losing what they have at present. I fully accept that any discussion of bed norms must be hedged around with many qualifications before being translated into beds.

R. G. Priest Registrar

\section{Consultant psychiatrist in mental handicap DeAr SIRS}

I read the article 'The Role of the Consultant Psychiatrist in Mental Handicap' by Caroline Marriott (Bulletin, December 1986, 10, 347-348) with much interest.

Dr Marriott seems to support the view that the Consultant Psychiatrist in Mental Handicap should take a full share of all services for the mentally handicappedalbeit endorsed by the DHSS (NI) in 1978. I feel that, for far too long, services for the mentally handicapped have been unsatisfactory because of the concept of the Consultant in Mental Handicap, dealing with mental to dental problems of the mentally handicapped.

The admission of a large number of mentally handicapped people (irrespective of their needs) to hospitals for the mentally handicapped aided and abetted this concept. As a direct result of this, other medical specialists and General Practitioners got used to the idea that any medical problem should be dealt with by the Consultant in Mental Handicap.

The role of Consultant in Mental Handicap has crystallised at last and most Consultants would prefer to call themselves Consultant Psychiatrist in Mental Handicap, which has the blessing of the Royal College of Psychiatrists as well.

The Consultant Psychiatrist in Mental Handicap should practise psychiatry and leave non-psychiatric medical problems to generic services. In fact, Dr Marriott mentions that "Consultants in Mental Handicap must work closely with all other medical and non-medical professionals likely to be in contact with mentally handicapped people."

But the initiative of disengaging from non-psychiatric problems and making other medical specialists and General Practitioners interested and involved in the problems of the mentally handicapped must come from Psychiatrists in Mental Handicap. It is easier said than done but can be achieved with energy, enthusiasm and persuasion and, most importantly, by face to face approaches to all the people concerned, as many medical specialists of different disciplines and General Practitioners need education, re-orientation and reassurance in order to deal with the problems of people with mental handicap.

With the rotation of junior psychiatric posts in Psychiatry of Mental Handicap, in the course of time General Psychiatrists should be able to cope with the psychiatry of mental handicap and joint appointments will occur more frequently, but in every district there is a need for at least one full time Consultant Psychiatrist in Mental Handicap. This will go a long way in changing the attitudes of the laymen and professionals and in re-organising hospitals for the mentally handicapped, with a reduction in the number of beds (and in smaller accommodation, preferably bungalows $4-6$ bedded with single rooms) and developing community homes, some of which, ideally, will have to be run by the NHS.

The job of Psychiatrist in Mental Handicap is extremely interesting, fascinating and challenging but it could be very dull, depressing and thoroughly frustrating depending on what we make of it and how able we are in initiating changes and how successful we are in making others accept these changes.

\section{Windsor Unit}

D. Chakraborti

King's Lynn, Norfolk

\section{Prejudice and mental handicap \\ Dear Sirs}

I was recently shown a copy of Public Service, NALGO's publication for December 1986, in which it was reported of Sir Brian Rix, the Secretary-General of MENCAP, "The mentally handicapped", he declares, "don't need locking up, they don't need drugs or psychiatrists".

Shortly after reading this I was asked urgently to see a mentally handicapped young man who had become agitated and had begun to attack his elderly parents. Under my care at present are a mentally handicapped man who has killed, another who has threatened people with a knife, and a woman who has set fires. On Christmas Day I received a call from a duty social worker anxious about a mentally handicapped man who was enjoying this community care by ordering about his ailing father and mother after having broken most of their crockery.

It is a pity that in mental handicap time and energy appear still to be dissipated on denigrating hospitals, where the vast proportion of patients since 1959 have been informal and not locked away, on sniping at psychiatrists, and perpetuating divisiveness. In practice over the years the difficulty has been attracting psychiatrists to take an interest in mental handicap, not the opposite. In fact the trend away from institutional care for mental handicap has paralleled the growth in the number of psychiatrists in this field and their general philosophy of not hospitalising mentally handicapped people, but developing out-patient and community support services. 